\title{
Exploring the Impact of Burstiness on the Service Process at the Cash Register
}

\author{
Detlef Hartleb \\ ETSIST, Universidad \\ Polit'ecnica de Madrid \\ Madrid, Spain \\ dethar@gmx.de
}

\author{
Andreas Ahrens \\ Department of Electrical \\ Engineering and Computer Science, \\ Hochschule Wismar, University of \\ Technology, Business and Design \\ Wismar, Germany
}

\author{
Jelena Zascerinska \\ Centre for Education and \\ Innovation Research \\ Riga, Latvia
}

\begin{abstract}
The service process is the key phase in any queue system applied to business and industry operations. The service process in shops is defined as the payment process at the cash register. The service process consists of two elements or sub-processes: the waiting in the queue to the cash register as well as the payment processing (scanning the goods, giving receipts to customers, etc). Analysis of burstiness as the indicator of the service process has been well-established. Against this background on burstiness as the indicator of the service process, burstiness is also defined as a factor that influences the service process. However, burstiness as a factor in the service process has not attracted a lot of research attention. The aim of this paper is to analyse burstiness as a factor in the service process underpinning the elaboration of scenarios of the service process for the queue management purposes. The present work mostly employs theoretical methods: scientific literature analysis, synthesis, modelling, comparison, and systematization. The theoretical research results in the outline of the conceptual framework for exploring the impact of burstiness on the service process. The key concepts have been identified, namely binary customer behaviour, buyers' burstiness, bottlenecks' emergence at the server, and queue management. The logical chain of the development has been emphasized: binary customer behaviour $\rightarrow$ buyers' burstiness $\rightarrow$ bottlenecks' emergence at the check-out station or cash register (server) $\rightarrow$ queue management. The presented logical chain allows finding out that buyers' burstiness leads to the queue appearance in the service process. In turn, queue appearance requires queue management measures. Hence, buyers' burstiness influences on the decisions in regard to queue management within the service process. Further on, two functions of buyers' burstiness are defined: the indicators of the service process, and the factor that influences the service process. This bi-modal role of buyers' burstiness in the service process highlights the complex nature of the queue
\end{abstract}

management. Five scenarios of the service process will allow using a combination of queue management measures in each scenario or even between scenarios. The findings of the comparative study propose the structure of the service process as the unity of the waiting in the queue to the cash register and the payment processing at the cash register, i.e. scanning of the goods and the payment. The present research has some limitations. Further research tends to validate the model of five scenarios of the service process for the queue management purposes. Comparative studies on buyers' burstiness in the service process will be continued, too.

Keywords - binary customer behaviour, buyers' burstiness, bottlenecks' emergence at the check-out station (server), queue management.

\section{INTRODUCTION}

The service process or, in other words, server is a key component in industrial and business operations [1]. Figure 1 as depicted in [1] shows the service process or, in other words, the payment process in the buying process chain [1].

Phase 1:
customer arrival $\rightarrow \begin{gathered}\text { Phase 2: } \\ \text { selection of goods }\end{gathered} \rightarrow \begin{gathered}\text { Phase 3: } \\ \text { payment process }\end{gathered} \rightarrow \begin{gathered}\text { Phase 4: } \\ \text { departure }\end{gathered}$

Fig. 1. The key phases in business operations [1].

Figure 2 reveals that the service process includes two sub-processes [1]:

- $\quad$ waiting in the queue to the cash register, and

- $\quad$ the payment processing at the cash register. 


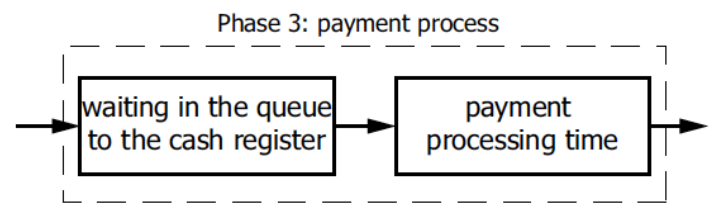

Fig. 2. The elements of the service process [1].

It should be pointed that the service process as the unity of waiting in the queue to the cash register and the payment processing was analysed through generating functions [1] as the generating function offers closed-form solutions when modelling bursty business processes [2]. Closedform solutions are an advantage when using a single function instead of analysing a sequence of infinite length [2]. In the analysis of the service process, generating functions were used for the analysis of the free time intervals between buyers to the cash register as a part of the payment process [1].

Similar concepts in regard to the presented service process were later presented

- $\quad$ in [3] as illustrated in Figure 3 developed by Kiataramkul and Neamprem [3], and

- in [4] as disclosed in Figure 4 created by Cheong and Chia [4].

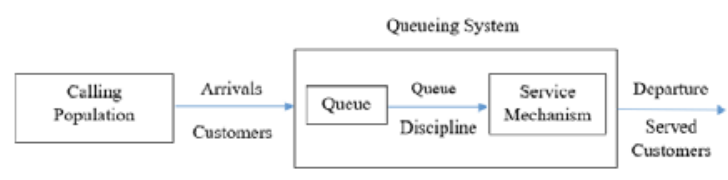

Fig. 3. The basic queueing process [3].

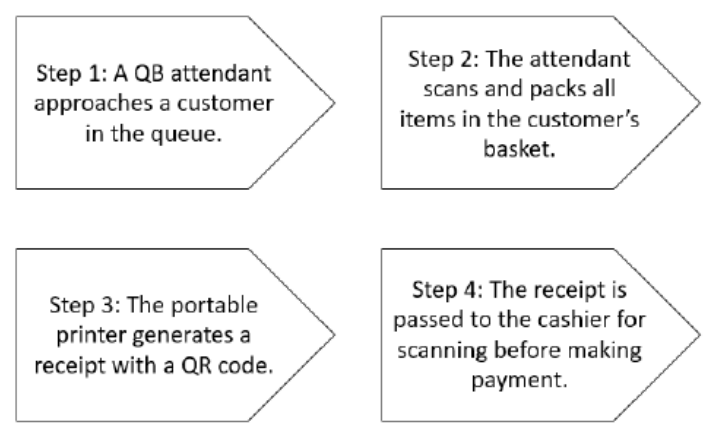

Fig. 4. Process Flow for Queue Buster [4].

Table 1 demonstrates the results of the comparison of the three concepts, namely

- $\quad$ the service process by [1],

- $\quad$ the queueing process by [3], and

- $\quad$ the queue buster [4].
TABLE 1 RESUlTS OF THE COMPARISION OF THREE CONCEPTS

\begin{tabular}{|c|c|c|c|}
\hline \multirow{2}{*}{$\begin{array}{l}\text { Concep- } \\
\text { tual ap- } \\
\text { proach }\end{array}$} & \multicolumn{3}{|c|}{ Compared elements } \\
\hline & $\begin{array}{c}\text { Process } \\
\text { structure }\end{array}$ & $\begin{array}{l}\text { Process } \\
\text { units of } \\
\text { analysis }\end{array}$ & Process indicators \\
\hline $\begin{array}{l}\text { The } \\
\text { service } \\
\text { process } \\
{[1]}\end{array}$ & $\begin{array}{l}\text { - Waiting in } \\
\text { the queue to } \\
\text { the cash } \\
\text { register, } \\
\text { - The payment } \\
\text { processing }\end{array}$ & $\begin{array}{l}\text { The unity } \\
\text { of the two } \\
\text { elements: } \\
\text { - Waiting in } \\
\text { the queue } \\
\text { to the cash } \\
\text { register, } \\
\text { - The } \\
\text { payment } \\
\text { processing }\end{array}$ & $\begin{array}{c}\text { Burstiness that } \\
\text { includes two } \\
\text { parameters: } \\
\text { • Buyers' } \\
\text { probability: } \\
\text { buyers' waiting } \\
\text { times in the queue } \\
\text { and buyers' service } \\
\text { (payment } \\
\text { processing) times } \\
\text { • Buyers' } \\
\text { concentration }\end{array}$ \\
\hline $\begin{array}{l}\text { The } \\
\text { queueing } \\
\text { process } \\
\text { [3] }\end{array}$ & $\begin{array}{c}\text { • Queue } \\
\text { • Service } \\
\text { mechanism }\end{array}$ & $\begin{array}{l}\text { - Queue } \\
\text { - Service } \\
\text { channels }\end{array}$ & $\begin{array}{c}\text { - Average queue } \\
\text { length, } \\
\text { - The average total } \\
\text { work in process, } \\
\text { - The average } \\
\text { waiting time, } \\
\text { - The average total } \\
\text { time }\end{array}$ \\
\hline $\begin{array}{l}\text { The } \\
\text { queue } \\
\text { buster [4] }\end{array}$ & $\begin{array}{c}\text { • Customer } \\
\text { approaching } \\
\text { in the queue } \\
\text { - Scan and } \\
\text { pack } \\
\text { - QR code } \\
\text { generation } \\
\text { • Receipt } \\
\text { scanning and } \\
\text { payment }\end{array}$ & $\begin{array}{c}\text { - Scan and } \\
\text { Pack } \\
\text { Time/Item } \\
\text { - Payment } \\
\text { Time } \\
\text { • Total } \\
\text { Time }\end{array}$ & $\begin{array}{l}\text { • Wait Time, } \\
\text { • System Time, } \\
\text { • System Length }\end{array}$ \\
\hline
\end{tabular}

Table 2 described burstiness as the indicator of the service process.

TABLE 2 Burstiness As the IndiCAtor of THE SERVICE Process

\begin{tabular}{|c|c|c|c|c|}
\hline \multirow[b]{2}{*}{$\begin{array}{c}\text { Indica- } \\
\text { tor }\end{array}$} & \multicolumn{4}{|c|}{ Indicators elements } \\
\hline & \multicolumn{3}{|c|}{ Buyers' probability } & $\begin{array}{l}\text { Buyers' } \\
\text { concent }\end{array}$ \\
\hline \multirow{2}{*}{$\begin{array}{l}\text { Bursti- } \\
\text { ness }\end{array}$} & \multirow{2}{*}{$\begin{array}{l}\text { - buyers' } \\
\text { waiting } \\
\text { times in the } \\
\text { queue to the } \\
\text { cash } \\
\text { register }\end{array}$} & \multicolumn{2}{|c|}{$\begin{array}{l}\text { - buyers' service (payment } \\
\text { processing) times at the cash } \\
\text { register }\end{array}$} & \multirow{2}{*}{$\begin{array}{l}\bullet \\
\text { buyers' } \\
\text { concen } \\
\text { tration }\end{array}$} \\
\hline & & $\begin{array}{l}\text { - buyers‘ } \\
\text { service } \\
\text { time }\end{array}$ & $\begin{array}{c}\text { • free-time } \\
\text { intervals between } \\
\text { buyers }\end{array}$ & \\
\hline
\end{tabular}

Analysis of burstiness as the indicator of the service process has been well-established [5] - [9].

Against this background on burstiness as the indicator of the service process, burstiness is also defined as a factor [10] that influences the service process [11]. Figure 5 reflects the both functions of burstiness in the service process.

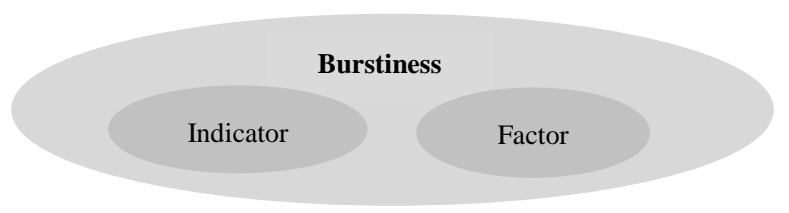

Fig. 5. Burstiness functions. 
Hence, burstiness is a bi-modal phenomenon:

- $\quad$ on the one side, burstiness as the indicator is used to determine developmental dynamics of the object [12], and

- on the other hand, burstiness as a factor changes the service process.

It should be noted that by bi-modal phenomenon, a phenomenon that obtains or exhibits two contrasting modes or forms is meant [13].

However, burstiness as a factor in the service process has not attracted a lot of research attention.

The aim of this paper is to analyse burstiness as a factor in the service process underpinning the elaboration of scenarios of the service process for the queue management purposes.

The present work mostly employs theoretical methods: scientific literature analysis, synthesis, modelling, comparison, systematization.

The remaining part of this paper is organized as follows: Section II introduces the conceptual framework of the research. The impact of buyers' burstiness on the service process is theoretically analysed in section III followed by five scenarios of the service process aimed at the queue management. Finally, some concluding remarks are given in Section IV.

\section{CONCEPTUAL FRAMEWORK}

Burstiness is a factor that influences the service process [1]. It should be noted that by factor, a reason of phenomenon change is meant [14].

Burstiness that influences the service process is related to customers [11]. In the present work, a customer is the overall term. A customer refers to anything and anyone that arrives at a facility and requires service. Examples of customers are shoppers at the check-out station or cars at the traffic light. The term "customer" has received a variety of definitions. In scientific literature, customer and client are synonymously used. Further, the term of "lost customers" is introduced by Sharma [15]. Customer also includes customer abandonment behaviour [16] in regard to a customer who stopped trying to receive a service due to a number of reasons. The term of "blocked customers" describes one who retries to get a service after a random amount of time [15]. Hence, these researchers have established the understanding of the customer behaviour based on the reception of service.

The present research is based on the concept of binary customer behaviour as depicted in Figure 6 [11].

Binary customer behaviour means to buy or not buy [17]. The use of the concept of binary behaviour allows differentiating customers into [17]

- $\quad$ visitors (i.e. who visit a shop but does not buy anything) and
- $\quad$ buyers (who visit a shop and buy a product).

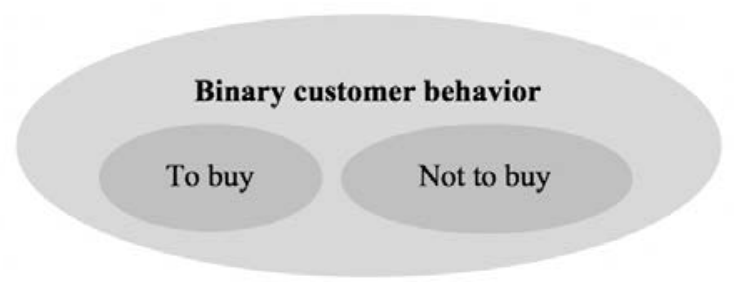

Fig. 6. Elemenst of customer binary option [11].

Buyers are further differentiated into two types [18]:

- $\quad$ highly delay-sensitive but only check-out a few items, and

- highly delay-insensitive but check-out many items.

It should be noted that the authors of the present work have enhanced the buyers' differentiation proposed by Tang, Guo, and Wang [18]. The authors of the present contribution introduce two more types of buyers:

- $\quad$ highly delay-sensitive buyer who only checksout many items, and

- highly delay-insensitive buyer who checksout a few items.

Consequently, the overall term "customer" is used in the same meaning by Sharma [15] and the authors of the present work. The terms "lost customer" and "visitor" are used synonymously. Table 3 shows the inter-relationships between customer, client, visitor, lost customer, customer abandonment behaviour, buyer, highly delay-sensitive buyer who only checks-out a few items, highly delaysensitive buyer who only checks-out many items, highly delay-insensitive buyer who checks-out a few items, and highly delay-insensitive buyer who checks-out many items.

TABLE 3 TERMS USED IN THE RESERACH

\begin{tabular}{|c|c|c|c|c|}
\hline \multicolumn{5}{|c|}{ Customer / Client } \\
\hline $\begin{array}{c}\text { Visitor, } \\
\text { Lost } \\
\text { customer, } \\
\text { Customer }\end{array}$ & \multicolumn{4}{|c|}{ Buyer } \\
\hline & $\begin{array}{l}\text { highly } \\
\text { delay- } \\
\text { sensitive } \\
\text { buyer } \\
\text { who only } \\
\text { checks- } \\
\text { out a few } \\
\text { items }\end{array}$ & $\begin{array}{l}\text { highly } \\
\text { delay- } \\
\text { sensitive } \\
\text { buyer } \\
\text { who } \\
\text { checks- } \\
\text { out many } \\
\text { items }\end{array}$ & $\begin{array}{l}\text { highly } \\
\text { delay- } \\
\text { insensitiv } \\
\text { e buyer } \\
\text { who only } \\
\text { checks- } \\
\text { out a few } \\
\text { items }\end{array}$ & $\begin{array}{c}\text { highly } \\
\text { delay- } \\
\text { insensitive } \\
\text { who } \\
\text { checks-out } \\
\text { many items }\end{array}$ \\
\hline
\end{tabular}

Buyers' burstiness influences the service process [19]. Buyers' burstiness corresponds to an enhanced activity level over a short period of time followed by long periods of inactivity [19]. Buyers' bursty arrival at the server influences the service process at the cash register in a shop. 
Buyers' bursty arrival at the server leads to the emergence of a bottleneck [2]. It should be noted that bottlenecks limit the flow of customers, services or products, etc [2]. A bottleneck emerges when single business processes within the business system operate at their capacity limit or beyond [2]. Due to the bottleneck, a queue appears [2]. Hence, the significance of queue management has become apparent.

It should be pointed that Table 4 shows the relationships between queuing systems, customer and server.

TABLE 4 THE RELATIONSHIPS BETWEEN QUEUING SYSTEMS, CUSTOMER AND SERVER

\begin{tabular}{|c|c|c|}
\hline $\begin{array}{c}\text { Queuing } \\
\text { System }\end{array}$ & Customer & Server \\
\hline Supermarket & Buyer & Cash register \\
\hline Airport & Passenger & Check in counter \\
\hline Bank & Client & Cash machine \\
\hline
\end{tabular}

The elaboration of this conceptual framework allows identifying the key concepts underlying the present research, namely

- binary customer behaviour,

- buyers' burstiness,

- bottlenecks' emergence at the server, and

- queue management.

The study presents a potential model for development indicating how the steps of the process are related following a logical chain: binary customer behaviour $\rightarrow$ buyers' burstiness $\rightarrow$ bottlenecks' emergence at the server $\rightarrow$ queue management. The presented logical chain allows finding out that buyers' burstiness leads to the queue appearance in the service process. In turn, queue appearance requires queue management measures. Figure 7 reveals the inter-relationships between the buyer burstiness, the service process and the queue management.

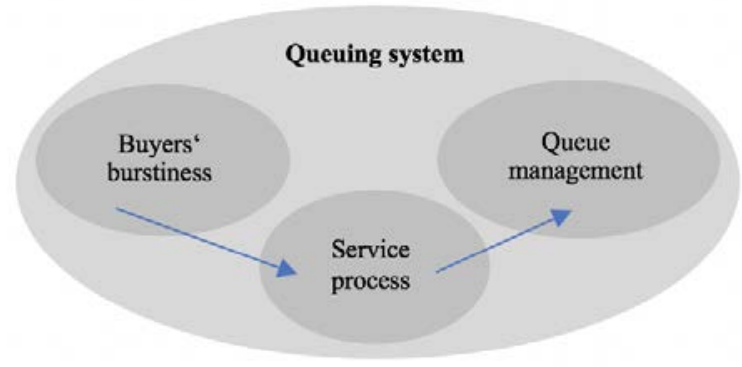

Fig. 7. The inter-relationships between the buyer burstiness, the service process and the queue management.

The presented conceptual framework directs the researchers to explore the impact of burstiness on the service process aimed at queue management.

\section{IMPACT OF BUYERS’ BURSTINESS ON THE SERVICE PROCESS}

Impact is defined as the influence on the decisions (regardless of outcome) that shape people's lives, communities, governance, the environment, and elsewhere [20].

Burstiness is used to support decision making through designation of a tendency in a field of scientific investigation [21] as pointed in Figure 8 [6].

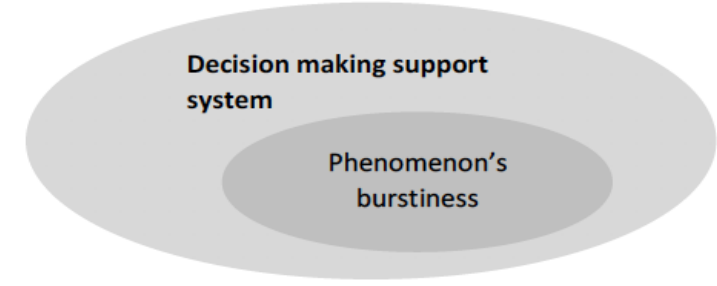

Fig. 8. The inter-connections between decision making support system and phenomenon's burstiness [6].

Consequently, buyers' burstiness influences the decisions on queue management of the service process. By queue management, planning, organizing, leading, and controlling the queuing system aimed at organising an efficient service process in order to reduce customer waiting times in the queue to the cash register or payment processing times at the cash register. The organization of the smooth flow of the service process increases [1]

- the customers' satisfaction with the service, and

- customers' loyalty to the serving company.

For the estimation of the impact of buyers ' burstiness on the service process, evaluation of buyers ' burstiness can be carried out. One of the reasons of the impact evaluation is the situation where decisions need to be made about whether and/or how to adapt, scale-up, mainstream or replicate projects or processes [22]. Impact evaluations are used in these circumstances because more certainty is required about the changes brought about through these kinds of intervention [22].

It is worth noting that the service process shown in [1] can be described by

- $\quad$ a buyer probability pe (a visitor becomes with a probability $\mathrm{p}_{\mathrm{e}} \mathrm{a}$ buyer), and

- a buyer concentration (describing the level of burstiness between buyers $\alpha$ defined in [1]).

For a given level of concentration, probability can be low or high. The probability depends on

- the number of customers in the shop as well as

- $\quad$ on the number of bought goods.

Table 5 presented in [9] indicates buyers' burstiness' constructs and levels for the impact measurement. 
TABLE 5 BuYers’ BuRSTINESS CONSTRUCTS AND LEVELS [9]

\begin{tabular}{|c|c|c|c|c|c|c|}
\hline \multirow{3}{*}{$\begin{array}{c}\text { Indica } \\
\text { tor }\end{array}$} & \multirow{3}{*}{ Constructs } & \multicolumn{5}{|c|}{ Levels } \\
\hline & & 1 & 2 & 3 & 4 & 5 \\
\hline & & $\begin{array}{l}\text { Very } \\
\text { low }\end{array}$ & Low & $\begin{array}{l}\text { Ave } \\
\text { rage }\end{array}$ & High & $\begin{array}{l}\text { Very } \\
\text { high }\end{array}$ \\
\hline \multirow{2}{*}{$\begin{array}{l}\text { Bursti } \\
\text { ness }\end{array}$} & $\begin{array}{c}\text { Probability } \\
p_{e}\end{array}$ & $\begin{array}{l}\text { Low } \\
\text { or } \\
\text { high }\end{array}$ & $\begin{array}{l}\text { Low } \\
\text { or } \\
\text { high }\end{array}$ & $\begin{array}{l}\text { Low } \\
\text { or } \\
\text { high }\end{array}$ & $\begin{array}{l}\text { Low } \\
\text { or } \\
\text { high }\end{array}$ & $\begin{array}{l}\text { Low } \\
\text { or } \\
\text { high }\end{array}$ \\
\hline & $\begin{array}{l}\text { Concentra- } \\
\text { tion }(1-\alpha)\end{array}$ & $\begin{array}{c}0.0 \\
- \\
0.10\end{array}$ & $\begin{array}{c}0.11 \\
- \\
0.39\end{array}$ & $\begin{array}{c}0.41 \\
- \\
0.59\end{array}$ & $\begin{array}{c}0.60 \\
- \\
0.79\end{array}$ & $\begin{array}{c}0.80 \\
- \\
1.0\end{array}$ \\
\hline
\end{tabular}

Buyers' burstiness is limiting the service process. [1].

A burstiness level serves as an indicator of bottlenecks

A high level of burstiness, expressed by the buyers concentration, increases the possibilities of bottleneck emergence [1].

The payment processing times at the cash register are quite regular [1]. However, the analysis of the free time intervals at the cash register describing the buyer waiting in the queue to the cash register allows drawing the conclusion on its bursty behaviour [1]. The bursty behaviour of the cashier free time intervals implies long breaks that alternate with many short breaks [1].

TABle 6 SCEnARIOS OF THE SERVICE Process

\begin{tabular}{|c|c|c|c|c|c|c|}
\hline $\begin{array}{c}\text { Pro } \\
\text { cess }\end{array}$ & \multicolumn{3}{|c|}{ The service process } & \multicolumn{2}{c|}{ Traffic flow } \\
\hline $\begin{array}{c}\text { Process } \\
\text { element } \\
\text { s }\end{array}$ & $\begin{array}{c}\text { Waiting in the } \\
\text { queue to the cash } \\
\text { register }\end{array}$ & \multicolumn{2}{c|}{$\begin{array}{c}\text { The payment } \\
\text { processing }\end{array}$} & $\begin{array}{c}\text { Sce } \\
\text { na } \\
\text { rio } \\
\text { Nr }\end{array}$ & $\begin{array}{c}\text { Queue } \\
\text { descript } \\
\text { ion }\end{array}$ \\
\hline $\begin{array}{c}\text { Const- } \\
\text { ructs }\end{array}$ & $\begin{array}{c}\text { Pro } \\
\text { ba } \\
\text { bility }\end{array}$ & $\begin{array}{c}\text { Concen } \\
\text { tration }\end{array}$ & $\begin{array}{c}\text { Pro } \\
\text { babili } \\
\text { ty }\end{array}$ & $\begin{array}{c}\text { Conc } \\
\text { entra } \\
\text { tion }\end{array}$ & & \\
\hline & Low & Low & Low & Low & 1 & $\begin{array}{c}\text { No } \\
\text { queuin } \\
\text { g }\end{array}$ \\
\cline { 2 - 7 } & High & Low & Low & Low & 2 & $\begin{array}{c}\text { Pre- } \\
\text { Queuin } \\
\text { g }\end{array}$ \\
\cline { 2 - 6 } & High & High & Low & Low & 3 & $\begin{array}{c}\text { Queuin } \\
\text { g }\end{array}$ \\
\cline { 2 - 6 } & High & High & High & Low & 4 & $\begin{array}{c}\text { Pre-traf } \\
\text { fic jam }\end{array}$ \\
\cline { 2 - 6 } & High & High & High & High & 5 & $\begin{array}{c}\text { Traf } \\
\text { fic jam }\end{array}$ \\
\hline
\end{tabular}

Based on these findings of the impact of burstiness on the service process, scenarios of the queue within the service process can be identified. For modelling purposes, Levels 1-3 are used as a low level, and Levels 4-5 - as a high level. Five scenarios of the service process for the queue management purposes are described in Table 6.

\section{CONCLUSIONS}

The theoretical research results in the outline of the conceptual framework for exploring the impact of burstiness in the service process. The key concepts have been identified, namely
- binary customer behaviour,

- buyers' burstiness,

- bottlenecks' emergence at the server, and

- queue management.

The logical chain of the development has been emphasized: binary customer behaviour $\rightarrow$ buyers' burstiness $\rightarrow$ bottlenecks' emergence at the server $\rightarrow$ queue management. The presented logical chain allows finding out that buyers' burstiness leads to the queue appearance in the service process. In turn, queue appearance requires queue management measures. Hence, buyers' burstiness influences the decisions in regard to queue management within the service process.

Further on, two functions of buyers' burstiness are defined:

- $\quad$ the indicator of the service process, and

- the factor that influences the service process.

This bi-modal role of buyers' burstiness in the service process highlights the complex nature of the queue management. Five scenarios of the service process will allow using a combination of queue management measures in each scenario or even between scenarios.

The findings of the comparative study presented in Table 1 propose the structure of the service process as the unity of the waiting in the queue to the cash register and the payment processing.

The present research has some limitations. A limitation is the conceptual framework based on the key concepts, namely

- binary customer behaviour,

- buyers' burstiness,

- bottlenecks' emergence at the server, and

- queue management.

Another limitation is the comparative study carried out on the works found via the google search. If the access to other databases would be available, the other findings of the comparative study could be outlined.

The two functions of buyers' burstiness also could limit the investigation of the service process. If other functions of buyers' burstiness within the service process would be determined they could help extend the understanding of the organization of the service process.

Further research tends to validate the model of five scenarios of the service process for the queue management purposes. Comparative studies on buyers' burstiness in the service process will be continued, too.

\section{REFERENCES}

[1] D. Hartleb, A. Ahrens, O. Purvinis, J. Zasccerinska, and D. Miceviciene, D. "Internal and External Factor Analysis in Bottleneck Detection in Shop Sales: The Case of Grocery Shops in Lithuania”, in Proceedings of the 10th International Conference on Pervasive and Parallel Computing, Communication and Sensors (PECCS 2020), pages 53-60. 
[2] D. Hartleb, A. Ahrens, and J. Zascerinska. “Conceptual Framework on Use of Generating Functions for Modeling the Payment Process at Cash Register”, in Edited by Piet Kommers and Pedro Isaías. Proceedings of the 19th International Conference e-Society 2021, 3- 5 MARCH, 2021, pp. 269-274. Organised by IADIS, 2021. ISBN: 978-989-8704-26-9.

[3] C. Kiataramkul and K. Neamprem, "Simulation of Queueing System for Commercial Bank in University: Case Study of Bangkok Bank at King Mongkut's University of Technology North Bangkok,” in 2019 Research, Invention, and Innovation Congress (RI2C), Bangkok, Thailand, 11-13 December 2019, 2019, pp. 1-4.

[4] M. L. F. Cheong and Y. Q. Chia, "Simulation Model to Evaluate Effectiveness of Queue Management Tool in Supermarket Retail Chain,” in 2019 IEEE International Conference on Industrial Engineering and Engineering Management (IEEM), 15-19 December 2019, pp. 606-610.

[5] A. Ahrens, O. Purvinis, D. Hartleb, J. Zaščerinska, and D. Micevičienė. "Analysis of a Business Environment using Burstiness Parameter: The Case of a Grocery Shop”, in Edited by Andreas Ahrens, Luis Gomes and César Benavente-Peces, Proceedings of 9th International Joint Conference on Pervasive and Embedded Computing and Communication Systems (PECCS 2019), pp. 49-56. 19-20 September 2019. Vienna, Austria. Printed in Portugal. ISSN: 2184-2817. ISBN: 978-989-758-385-8. Depósito Legal: 460067/19, 2019, pp. 49-56.

[6] A. Ahrens, O. Purvinis, and J. Zaščerinska. "Gap Structure and Characteristic Properties for Analysing Buyers’ Burstiness in EBusiness process”, in Edited by Luis Gomes, Andreas Ahrens, César Benavente-Peces and Mohammad S. Obaidat, Proceedings of 8th International Joint Conference on Pervasive and Embedded Computing and Communication Systems (PECCS 2018), pp. 2334. 29-30 July 2018. Porto, Portugal. Printed in Portugal. ISSN: 2184-2817. ISBN: 978-989-758-322-3. Depósito Legal: 442620/18. 2018, pp. 23-34

[7] A. Ahrens and J. Zaščerinska. "E-Shop Visitors’ Burstiness as a Predictor of Performance - The Case of eBay", in ICETE 2017 Proceedings of the 14th International Joint Conference on eBusiness and Telecommunications Volume 2: ICE-B, Madrid, Spain, July 24-26, 2017, pp. 78-82. ISBN: 978-989-758-257-8. Published by SCITEPRESS - Science and Technology Publications, Lda. Printed in Portugal, 2017.

[8] A. Ahrens and J. Zaščerinska. "Analysing Buyers` Burstiness in EBusiness: Parameter Estimation and Practical Applications”, in ICETE 2017 Proceedings of the 14th International Joint Conference on e-Business and Telecommunications Volume 2: ICE-B, Madrid, Spain, July 24-26, 2017, pp. 71-77. ISBN: 978-989-758-257-8. Published by SCITEPRESS - Science and Technology Publications, Lda. Printed in Portugal, 2017.

[9] A. Ahrens, O. Purvinis, J. Zaščerinska, and N. Andreeva. "Education for Health Society: Indicators of Burstiness in Research”, in Journal Education in a Changing Society, Volume 1 (2016), pp. 28-40. ISSN: 2351-6550, 2016, pp. 28-40. DOI: http://dx.doi.org/10.15181//atee.v1i0.1315.

[10] D. Hartleb, A. Ahrens, O. Purvinis, J. Zascerinska, and D. Miceviciene, "Internal and External Factor Analysis in Bottleneck Detection in Shop Sales: The Case of Grocery Shops in Lithuania,” in International Conference on Pervasive and Embedded Computing and Communication Systems (PECCS), Online Streaming, 03.-05. November 2020.

[11] A. Ahrens, O. Purvinis, J. Zaščerinska, and N. Andreeva. "Gap Processes for Modelling Binary Customer Behavior", in Proceedings of the 8th International Conference on Engineering and Business Education 8-9 October 2015, Østfold University College, Fredrikstad, Norway, pp. 8-13. Published by University of Wismar, Germany, 2015, pp. 8-13.

[12] J. Zaščerinska, J. Development of Students' Communicative Competence within English for Academic Purposes Studies. Verlag: Mensch \& Buch. 2013, 202 pp. ISBN-13: 978-3-86387359-2.

[13] A. Ahrens and J. Zaščerinska. "Students' Attitude to Interdisciplinary Research", in Society, Integration, Education. Proceedings of the International Scientifical Conference. Volume I: Higher Education Institutions Pedagogy, School Pedagogy, PreSchool Pedagogy. May, 23th-24th, 2014, - Rēzekne: Rēzeknes Augstskolas Izdevniecība, 2014, pp.13-23.

[14] A. Jacob, A. Ahrens, J. Zascerinska, and C. Benavente-Peces. "AHP-based Evaluation of the Acceptance of Autonomous Driving”, in Proceedings of the 10th International Conference on Pervasive and Parallel Computing, Communication and Sensors (PECCS 2020), pages 61-65.

[15] R. Sharma, "Mathematical Analysis of Queue with Phase Service: An Overview," Advances in Operations Research, vol. 2014, Article ID 240926, 19 pages, 2014, Dec 2014. [Online]. Available: https://doi.org/10.1155/2014/240926. [Accessed March 8, 2021].

[16] S. C. Ferrari and R. Morabito, “Application of queueing models with abandonment for Call Center congestion analysis,” Gestao \& Producao, vol. 27, 2020.

[17] D. Hartleb, A. Ahrens, O. Purvinis, and J. Zascerinska. “Analysis of Free Time Intervals between Buyers at Cash Register using Generating Functions”, in Proceedings of the 10th International Conference on Pervasive and Parallel Computing, Communication and Sensors (PECCS 2020) November 3 - 5, 2020 [Online Streaming], 2020, pp. 42-49.

[18] Y. Tang, P. Guo, and Y. Wang, "Equilibrium queueing strategies of two types of customers in a two-server queue," Operations Research Letters, vol. 46, no. 1, pp. 99 - 102, 2018. [Online]. Available: http://www.sciencedirect.com/science/article/pii/S0167637717303 243. [Accessed March 8, 2021].

[19] A. Ahrens and J. Zaščerinska. "Gap Processes for Analysing Buyers’ Burstiness in E-Business Process”, in Edited by Christian Callegari, Marten van Sinderen, Panagiotis Sarigiannidis, Pierangela Samarati, Enrique Cabello, Pascal Lorenz and Mohammad S. Obaidat, Proceedings of the 13th International Joint Conference on e-Business and Telecommunications (ICETE 2016) - Volume 2: ICE-B, pages 78-85. Published by SCITEPRESS Science and Technology Publications, Lda. Printed in Portugal, 2016, pp. 78-85.

[20] Federation for the Humanities and Social Sciences. "The Impacts of Humanities and Social Science Research. Working Paper", October 2014. Available: http://www.ideasidees.ca/sites/default/files/2014-10-03-impactproject-draft-report-english-versionfinal2.pdf. [Accessed March 8, 2021].

[21] J.B. Pierrehumbert. "Burstiness of Verbs and Derived Nouns", in D. Santos, K. Linden, and W. Ng'ang'a (Eds.) Shall we Play the Festschrift Game?: Essays on the Occasion of Lauri Carlson's $60^{\text {th }}$ Birthday. Springer Verlag, 2012.

[22] Intrac, Impact Evaluation, Intrac for cicil society, 2017. Available: https://www.intrac.org/wpcms/wpcontent/uploads/2017/01/Impact-evaluation.pdf. [Accessed March 8, 2021]. 